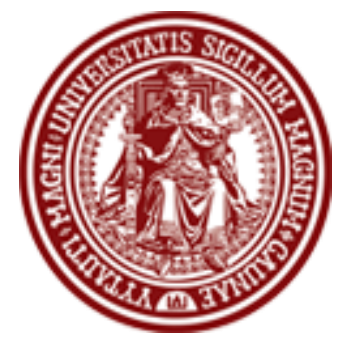

BALTIC JOURNAL OF LAW \& POLITICS

VOLUME 1 (2008)

ISSN 2029-0405

http://www.versita.com/science/law/bjlp

Cit.: Baltic Journal of Law \& Politics 1 (2008): 1-17

DOI: $10.2478 / v 10076-008-0001-5$

\title{
IMPORTANCE OF VOLUNTARY ENVIRONMENTAL PROGRAMMES \\ IN ENSURING COMPLIANCE OF LEGAL ENTITIES WITH THE REQUIREMENTS OF ENVIRONMENTAL LAW
}

\author{
LINAS MEŠKYS \\ Associate Professor; Dr. \\ Vytautas Magnus University Faculty of Law (Lithuania) \\ Contact information \\ Address: S. Daukanto str. 28, LT-44246 Kaunas, Lithuania \\ Phone: 370-37-327873 \\ E-mail address: I.meskys@tf.vdu.It
}

Received: July 12, 2008; reviews: 2; accepted: November 5, 2008.

\section{ABSTRACT}

Legal entities are among the most active participants of the social relations in modern society, but they also are becoming one of the main sources of environmental risks.

With the growing negative intervention of the economic activities of legal entities into environment, legal regulation of relations of economic activities to environment should not be oriented towards application of state enforcement mechanism solely. Compliance with the environmental law and prevention of its breaches can be ensured efficiently through implementing alternative environmental protection measures, having a preventive character and based on a voluntary basis.

However, a command and control mechanism, based on applying enforcement procedures to legal entities, which do not comply with the requirements of environmental law, still prevails in Lithuania. In this context, experience of other countries enables justified assuming that various environmental programmes, grounded on voluntary bases rather than on enforcement can be significantly more efficient for ensuring compliance of legal entities with the requirements of environmental regulations.

This article, through experience of the United States, analyses importance of voluntary environmental programmes in guaranteeing compliance of legal entities with the 
requirements of environmental law, and examines implementation of those programmes within the European Union and Lithuania.

\section{KEYWORDS}

Environmental law, voluntary environmental programmes, environmental self-auditing, voluntary disclosure. 


\section{INTRODUCTION}

Industrial and other economic activities have great impact on environment, and often these activities cause appearance of damage to environment. Definitely, one of the major subjects of development of industry, transport, energy and other branches of economy are private legal entities, which are among most active participants of social relations within modern civilised society. Legal entities, which mostly pursue profit, become one of the major sources of risks to the environment.

The above mentioned objective reasons create the need of efficient legal regulation, and environmental protection together with striving for ensuring harmonisation of economic, social and environmental interests becomes a priority for every state.

One of the primary means for ensuring compliance of legal entities with the environmental requirements is a state enforcement mechanism and an institution of amenability. However, increasing negative intervention into the environment, caused by economic activities of legal entities, legal regulation of relations between economic activities and the environment should not be oriented solely to application of state enforcement mechanism. It would be erroneous to think that only institution of legal amenability in environmental sphere, applied to legal entities, ensures prevention of infringements of law. State policy must be directed to establishing alternative means of environmental protection, developed on voluntary basis, and to their efficient implementation.

One of the most effective means, able to ensure compliance of legal entities with the environmental requirements, are economic incentives for legal entities. Legal entities must be interested in complying with environmental rules in force; it must be for such entities beneficial in terms of economics.

However, mechanism of command and control is increased and often given excess importance in Lithuania, and the legal doctrine does not pay sufficient attention to voluntary programmes on environmental protection, which have preventive importance.

Thus, this article aims at assessment of importance of voluntary programmes of environmental protection in ensuring compliance of legal entities with the requirement of environmental rules in force. For this purpose the article will represent the notion of voluntary programmes of environmental protection, will evaluate environmental self-auditing and mechanism of voluntary disclosure of violations of environmental regulations, also will analyse implementation of this mechanism within the European Union and Lithuania. 


\section{NOTION OF VOLUNTARY ENVIRONMENTAL PROGRAMMES}

A few decades ago many countries of the world have as an essential means for stimulating (enforcing) legal entities to comply with requirements of environmental law application of state enforcement mechanism. More over, states tried to solve environmental protection problems by applying various taxation, subsidies, command and control regulatory mechanism, ${ }^{1}$ tried to lay down mandatory environmental requirements.

But over the time most legal entities realised that complying with environmental regulations not only helps to avoid public enforcement, but also ensures security of business and production, helps to protect the environment and human health, and this leads to more favourable approach of clients, business partners, financial institutions and society, which consequently has direct impact on successful business development.

On the other hand, command and control mechanism was permanently criticised by economists because of its rigidity and high implementation costs, ${ }^{2}$ and that is why voluntary environmental programmes became an instrument of high importance in pursuing environmental goals.

The United States were one of the first countries in the world, where legal entities as their effort in compliance of their activities with the environmental requirements started to implement means of self-regulation. Besides those self regulatory measures of legal entities are aimed at protection of the environment and human health, they are implemented on expense of legal entities, so there is economy of public funds. For the United States an important task of the state has become encouragement of as many as possible legal entities for implementation of self-regulatory measures, ensuring compliance with the environmental law.

Self-regulatory measures are voluntary environmental programmes, based rather on voluntary bases instead of enforcement, during the last two decades have become an important tool of environmental policy in industrialised countries. ${ }^{3}$ Such environmental programmes include various environmental initiatives, participated

\footnotetext{
1 Thomas P. Lyon, John W. Maxwell, "Self-regulation, taxation and public voluntary environmental agreements," Journal of Public http://webuser.bus.umich.edu/tplyon/LyonMaxwellJPubE.pdf (accessed May 3, 2008).

2 Thomas P. Lyon, John W. Maxwell, "'Voluntary' Approaches to Environmental Regulation: A Survey," (January 1999): 1, http://ssrn.com/abstract=147888 (accessed January 14, 2008).

3 Allen Blackman, Thomas P. Lyon, Nicholas Sisto, "Voluntary Environmental Agreements When Regulatory Capacity Is Weak," (2006): 1, http://www.rff.org/Documents/RFF-DP-06-30.pdf (accessed January 14, 2008).
} 
by private legal entities and without state intervention or together with public institutions on a basis of partnership. ${ }^{4}$

Entities in industry and other branches of economics, without enforcement of traditional command and control or any other regulatory methods, applied by state, seek for positive impact on environmental processes in industry and other branches of economics. ${ }^{5}$ Voluntary environmental initiatives cover a lot of voluntary environmental protection programmes, of which among the most efficient are environmental self-auditing, voluntary disclosure of violations of environmental regulations, publication of environmental information or voluntary codes, which, according to declarations, are efficient means in changing corporate behaviour. Private enterprises often adopt those codes as preventive measures, helping to reduce risk of damages to environment and, thus, providing background for avoiding legal amenability. ${ }^{6}$

Voluntary programmes of entities of industry, manufacturing and other branches of economics (in other words 'initiatives' - auth. not.) in the sphere of environmental protection attained lots of attention of international organisations (UNO, Organization of Economic Cooperation and Development, EU). This attention was earned because such programmes enable assuming as regards their efficiency in achieving environmental goals. ${ }^{7}$

It has been noticed that both legal entities' unilateral environmental protection initiatives and initiatives, in which public institutions take part as partners, demand less material resources and are very efficient. In addition, those initiatives sometimes help solving such environmental problems, which are impossible solving by traditional command and control regulatory mechanism. ${ }^{8}$

Voluntary approaches to environmental protection are sometimes called the "next generation of environmental policies". In contrast to traditional mandatory policies such as direct regulations, these approaches rely on voluntary actions of firms to improve their environmental performances. ${ }^{9}$

\footnotetext{
${ }^{4}$ Business and Industry Advisory Committee to the OECD, BIAC Statement "Voluntary Approaches in

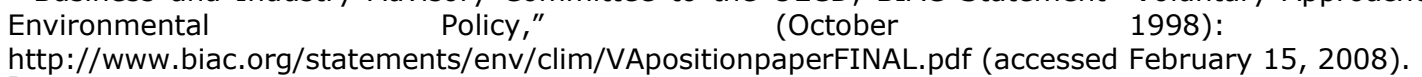

5 Environmental Commissioner of Ontario, Discussion Paper For Round Table On Self Regulation, Voluntary Compliance And Environmental Protection, (October 1996): 1, http://www.eco.on.ca/english/publicat/rndtbl1.pdf (accessed February 18, 2008).

${ }^{6}$ Productivity Commission, "Implementation of Ecologically Sustainable Development by Commonwealth Departments and Agencies," Report No. 5 (Canberra, AusInfo, 1999), available through www.pc.gov.au (accessed February 18, 2006).

BIAC Statement "Voluntary Approaches in Environmental Policy," supra note 4.

${ }^{8}$ Id.

9 Toshihiro Uchida, Paul J. Ferraro, "Can Encouraging Voluntary Development of Environmental Management Systems Augment Existing Regulations?" Water Policy Working Paper \#2005-015 (2005): 1, http://www.h2opolicycenter.org/pdf_documents/water_workingpapers/2005-015.pdf (accessed March 4, 2008).
} 
Advantages of voluntary environmental protection programmes in comparison to traditional command and control management mechanism consist of the fact that legal entities, who implement such initiatives, manufacture cleaner production, public funds are saved for implementation of environmental protection requirements and for ensuring compliance with such requirements, spending on management and administration of environmental protection are reduced, voluntary initiatives are implemented and realised more swiftly in comparison to legislation, relations and confidence between legal entities and public institutions are improved, in the context of rapidly changing economic life voluntary initiatives are more flexible and ambitious environmental goals are set, ${ }^{10}$ this way contributing to sustainable development goals.

However, it is worth mentioning that application of voluntary environmental protection is quite limited. Voluntary environmental protection initiatives are implemented to the extend, to which such an implementation is beneficial for legal entities (e. g., where by implementation of such initiatives it is possible to save costs, acquire global recognition, avoid state enforcement, etc.). The main objective of activities of legal entities is profit, so it is natural that legal entities pursue also real benefit while implementing voluntary environmental protection initiatives.

It is said that implementation of environmental protection initiatives ends when there is the end to business interests. Additionally, it is impossible to enforce all the legal entities to implement voluntary environmental programmes, as there are no possibilities for control of inappropriate, reckless or even detrimental implementation of those initiatives. Whereas voluntary environmental protection initiatives are implemented by different legal entities in different cultural, social and economic context, it is complicate to ensure global benefit of such initiatives. ${ }^{11}$

Because of this background voluntary environmental initiatives should be seen not separately, but systematically, evaluating importance of command and control regulation and also direct regulation measures in order to achieve environmental goals.

From economic perspective, voluntary environmental protection initiatives are more efficient than command and control regulation.

Voluntary approaches are tools that may effectively complement command and control mechanisms and economic instruments by improving the efficiency and effectiveness of environmental management regimes in meeting environmental

10 UNEP Multi-Stakeholder Workshop on Voluntary Initiatives, "Voluntary Initiatives: current status, lessons learned and next steps," UNEP discussion paper (Paris, September 20, 2000), http://www.uneptie.org/outreach/vi/reports/voluntary_initiatives.pdf (accessed August 8, 2006).

${ }^{11} I d$. 
objectives, but they are not meant to work on their own. ${ }^{12}$ On the other hand, in order to pursue environmental goals it would be the most efficient to combine voluntary environmental protection initiatives and other environmental measures, which have components of state enforcement.

Among the most important measures, which were introduced in the United States a few decades ago, were environmental self-auditing, also called environmental internal audit, self-auditing, or self-investigation, and self-disclosure or voluntary disclosure of violations of environmental regulations.

\section{ENVIRONMENTAL SELF-AUDITING AND VOLUNTARY DISCLOSURE OF VIOLATIONS OF ENVIRONMENTAL REGULATIONS}

In the United States, great number of legal entities, in order to comply with the environmental law in their activities, and also in order to avoid possible penalties or other state enforcement measures, applies environmental self-auditing mechanism, designed for detecting compliance or non-compliance of a legal entity with environmental law in force.

It is said that the challenge of complying with all of the applicable environmental regulations is formidable for any organization, and internal auditing, or self-auditing is increasingly being used to address this challenge. ${ }^{13}$ Whereas environmental self-auditing is aimed and targeted mostly at ensuring compliance with the environmental regulations, more over, whereas this mechanism requires less financial resources, enterprises, which implement internal audit, have attained support of public authorities as well. Besides, environmental self-auditing not only helps to avoid state enforcement measures, bur also increases social reliability of enterprises. Recently, when negative intervention of economic activities into environment has reached high level of risk, society has become very sensitive to issues of environmental protection. This feature of society is becoming a very important factor in competitive economy of states, as reorientation of the scale of social values from the priority of economical objectives onto economical, social and environmental priorities has direct effect onto legal entities, which take active part in economic activities. Legal entities, which harmonise their economical objectives with the social and environmental ones, earn reliance of their business partners, financial institutions and society (including clients), and this makes prerequisite for

\footnotetext{
12 Marc Paquin, Carla Sbert, "Towards Effective Environmental Compliance and Enforcement in Latin America and the Caribbean," (2004): 34,

http://www.unisfera.org/IMG/pdf/New_approaches_to_environmental_protection_vfinale3_ajout_.pdf (accessed January 14, 2008).

13 Fred N. Rubel, "The Basics of EH\&S Self-Auditing," EM, A\&WMA's Magazine for Environmental Managers (2006), http://www.environmental-expert.com/resulteacharticle4.asp?cid =6477\&codi=5984 (accessed November 28, 2006).
} 
those entities to successful development of their business. On the other hand, legal entities, who promote consumer approach to environment in their activities, receive more and more reprehension from their social partners. Those circumstances determine importance of self-auditing for legal entities in order to achieve successful business development and recognition of social partners and public.

It is necessary to mention that it would be difficult to find globally recognised and used notion of environmental self-auditing, but the most often the environmental self-auditing is described as programmes and measures used inside corporations, targeted at ensuring compliance of corporate activities with environmental regulations. ${ }^{14}$ Environmental self-auditing, which is performed by corporation's staff or third persons hired by a corporation, ${ }^{15}$ enables corporation to collect information on corporate operations, detect deviations from environmental regulations and thus diminish consequences of infringements of environmental regulations and also remedy those consequences or avoid infringements of environmental regulations at all. ${ }^{16}$

Firms derive a number of economic benefits from implementing compliance audits. Firms can detect noncompliance early, remedy problems that are discovered, and establish new procedures to prevent future violations. As a result, fines and penalties assessed by regulatory bodies may be reduced or eliminated. ${ }^{17}$

Supporters of the Audit Policy argue that it is an "efficient and economical means of ensuring and improving compliance with environmental laws and regulations." Opponents argue that this policy ultimately protects polluters from punishment, and thus will have a detrimental effect on the environment because facilities have less incentive to comply. ${ }^{18}$

Whereas environmental self-auditing promotes compliance with environmental regulations and rules and also prevents from violations of the environmental law, this self-regulatory measure should be seen as an important tool in achieving sustainable development goals. Legal entities, who have implemented environmental self-auditing mechanism, harmonise their activities with environmental requirements, seek for optimization of usage of natural resources, take other preventive measures and thus contribute to fulfilment of the aim of sustainable development.

\footnotetext{
14 Jay p. Kesan, "Encouraging Firms to Police Themselves: Strategic Presentations to Promote Corporate Self-Auditing," University of Illinois Law Review 155 (2000): 156, http://ssrn.com/abstract=263835 (accessed May 25, 2007).

${ }_{15}$ Fred N. Rubel, supra note 13.

${ }^{16}$ Harris Michael Ray, "Promoting Corporate Self-Compliance: An Examination of the Debate Over Legal Protection for Environmental Audits," 23 ECOLOGY L.Q. 663 (1996): 673-679.

17 Jay p. Kesan, supra note 14: 156.

18 Sarah Stafford "Does Self-Policing Help the Environment? EPA's Audit Policy and Hazardous Waste Compliance," Vermont Journal of Environmental Law 6 (2004-2005), http://www.vjel.org/journal/VJEL10022.html (accessed May 21, 2008).
} 
It is important that other means of environmental policy - self-disclosure of violations of environmental regulations - is closely related to environmental selfauditing.

In the year 1995 Environmental Protection Agency of the United States of America adopted the programme under the title 'Incentives for Self-Policing: Discovery, Correction and Prevention of Violations - Audit Policy', ${ }^{19}$ which was reviewed and updated in 2000 in order to ensure even greater compliance with the requirements of legal regulations protecting human health and the environment.

The main objective of the Audit Policy was to encourage facilities to implement "systematic, objective, and periodic" environmental auditing and to develop documented systematic procedures or practices which reflects the regulated entity's due diligence in preventing, detecting, and correcting violations. ${ }^{20}$

By Audit Policy programme enterprises are encouraged to detect, voluntarily report and correct violations of environmental regulations and Environmental Protection Agency of the USA reduces penalties or waives those penalties at all for such actions of enterprises. ${ }^{21}$

Implementation of the mechanism of self-disclosure of environmental violations should be seen as a state measure, encouraging legal entities to implement efficiently operating environmental self-auditing. This state measure, while providing specific benefits to legal entities (reduction in the amount of penalties or waiving penalties for disclosing entities), encouraged legal entities to more promptly introduce environmental self-auditing, which must be seen as a selfregulatory measure.

Audit Policy programme provides nine conditions, ${ }^{22}$ and entities that meet those conditions are eligible to $100 \%$ mitigation of applicable penalties. Companies that do not meet the first condition through the nine (systematic discovery of violations of the environmental protection law), but meet the other eight conditions, are eligible for $75 \%$ mitigation of any penalties. Environmental Protection Agency of the USA also recommend competent authorities waiving penalties for company violations, if that company meets at least two conditions through nine (regardless weather it meets the first condition, i.e. requirement of systematic discovery of

19 Environmental Protection Agency, Incentives for Self-Policing: Discovery, Disclosure, Correction and Prevention of Violations, (May 11, 2000),

http://www.epa.gov/compliance/resources/policies/incentives/auditing/auditpolicy.pdf (accessed 23 February, 2008).

20 Jodi L. Short, Michael W. Toffel, "Turning Themselves In: Why Companies Disclose Regulatory Violations," Center for Responsible Business, Working Paper Series Paper 17 (2005): 9, http://repositories.cdlib.org/crb/wps/17 (accessed 23 February, 2008).

${ }^{21} I d$.

22 1) Systematic Discovery of the Violation Through an Environmental Audit or a Compliance Management System; 2) Voluntary Discovery; 3) Prompt Disclosure; 4) Discovery and Disclosure Independent of Government or Third Party Plaintiff; 5) Correction and Remediation; 6) Prevent Recurrence; 7) No Repeat Violations; 8) Other Violations Excluded; 9) Cooperation. 
environmental violations), has performed environmental self-auditing, has detected and disclosed an environmental violation voluntarily and in good faith, and has taken purposeful actions in order to prevent recurrence of the violation in the future.

Despite obvious benefits of Audit Policy programme, this mechanism has not been widespread as rapidly as it would be required by the USA governmental institutions responsible for ensuring compliance with the environmental protection requirements and control. One of the obstacles to Audit Policy mechanism expansion is a probability that information disclosed by enterprises after performing environmental self-auditing will be used against those enterprises themselves, i.e. competent state authorities will penalise those enterprises for voluntarily disclosed violations of the environmental regulations and do not take account of set up criteria for applying reduced amount of penalty and for waiving penalties for violations. ${ }^{23}$ It is stated that corporate fear that the information disclosed will be used against corporations themselves, hinders wider spread and application of environmental self-auditing. ${ }^{24}$

But, as regards the United States of America, the above mentioned defect has been removed by developing the so called self-evaluated privilege (SEP) doctrine. At least twenty-two states of the USA have adopted regulations recognising environmental SEP, protecting confidentiality of the information disclosed during voluntary environmental self-auditing. ${ }^{25}$ Though the scope of SEP confidentiality differs in many states, the common feature of the privilege is protection of confidentiality of the information disclosed during environmental self-auditing and also prohibition of use of such information in civil, criminal or administrative proceedings. $^{26}$

Whereas essential element of voluntary self-disclosure of violations of environmental requirements mechanism is voluntary disclosure by legal entity of violations of the environmental law, committed by that entity, this mechanism should be seen as a very important measure, helping to reduce public costs for detecting and investigating violations of the environmental law and applying sanctions. Additionally, voluntary self-disclosure of infringements of the environmental protection law has a preventive impact on legal entities, encourages

\footnotetext{
${ }^{23}$ Alexander Pfaff, Chris William Sanchirico, John Lee, Daniel Prager, "Big Field, Small Potatoes: An Empirical Assessment of EPA's Self-Audit Policy," UVA Law and Economics Research Paper No. 02-02 (2004): 2, http://ssrn.com/abstract=307241 (accessed 23 February, 2008).

${ }^{24}$ Chris William Sanchirico, Alexander Pfaff, "Environmental Self-Auditing: setting the proper incentives for discovery and correction of environmental harm," Journal of Law, Economics, and Organization Vol. 16, No. 1 (April 2000): 189-208, http://jleo.oxfordjournals.org/cgi/content/abstract/16/1/189 (accessed 23 February, 2008).

25 Jay p. Kesan, supra note 14

${ }^{26}$ Jay p. Kesan, supra note 14.
} 
those entities to complying with the environmental requirements in the future, so it is possible to expect compromise among environmental, economic and social goals.

\section{ENVIRONMENTAL SELF-AUDITING AND SELF-DISCLOSURE OF VIOLATIONS OF ENVIRONMENTAL REGULATIONS IN THE EUROPEAN UNION AND THE LITHUANIAN REPUBLIC}

The equivalent to environmental self-auditing, widespread in the USA, is known in the European Union as well. On 19th March 2001, the European Parliament and the Council of the European Union has adopted Regulation (EC) No $761 / 2001,{ }^{27}$ allowing voluntary participation by organisations in a Community ecomanagement and audit scheme (EMAS), thus establishing the eco-management and audit scheme of the European Union and allowing voluntary participation by organisations in it in order to asses and improve environmental efficiency of organisations, also to provide relevant information to public and other parties concerned.

Regulation (EC) No 761/2001 has provided the notion of 'environmental audit', indicating that environmental audit shall mean a management tool comprising systematic, documented, periodic and objective evaluation of the efficiency of the organisation, management system and processes, and designed to protect the environment, with the aim of facilitating management control of activities which may have impact on the environment, assessing compliance with the environmental policy, including environmental objectives and targets of the organisation. ${ }^{28}$

The aim of the eco-management and audit scheme provided in the Regulation is encouraging organisations to permanent improvement of their environmental performance by establishing and implementing of environmental management schemes, evaluating performance of the schemes systematically, objectively and regularly, and by providing information on environmental performance to public and other parties concerned, also by starting an open dialog with them, actively involving employees in the organisation into activities of internal audit and providing those employees with the appropriate initial and advanced training. ${ }^{29}$

European Environmental Agency environmental audit describes as a management tool comprising a systematic, documented, periodic and objective

\footnotetext{
${ }^{27}$ Regulation (EC) No 761/2001 of the European Parliament and of the Council of 19 March 2001, Official Journal L: 200104 24, no. 114-1.

${ }^{28}$ Id., art. 2.

${ }^{29}$ Id., art. 1.
} 
evaluation of how well a project, organisation or equipment is performing with the aim of helping to safeguard the environment. ${ }^{30}$

On 15th March 2002, the Ministry of Environment of the Republic of Lithuania, by its Order No 113 supported the programme, laid down in Regulation (EC) No 761/2001 of the European Parliament and of the Council, allowing voluntary participation by organisations in a Community eco-management and audit scheme (EMAS), by providing the relevant implementation programme. ${ }^{31}$

For the purpose of this programme, eco-management and audit scheme (EMAS) is described as a voluntary scheme, designed for organisations desiring to commit to evaluation and improvement of their environmental performance. The main goal of EMAS consist of broadening the range of instruments used in the field of environmental protection and of using market-mechanisms to commit organisations to adopt pro-active approach in the activities in the mentioned field. ${ }^{32}$ In order to successfully implement this aim, organisations should get familiar with environmental protection aspects and environmental impact, and also do not limit themselves only to complying with environmental legislation and regulations. While applying those principles, there is increase in economic efficiency, the environmentally friendly conditions are provided, and there emerge competitive advantages of new type in international markets. Organisations decide on implementing this modern management system on voluntary basis and on their own expenses, as owing to the system organisations strengthen their export positions in competitive international market. ${ }^{33}$

The Regulation of the European Parliament and of the Council, and also the programme of the implementation of the Regulation, confirmed by the Order of the Ministry of Environment of the Republic of Lithuania, should be seen as means in pursuing objectives of sustainable development. Successful implementation of EMAS would enable seeking for compromise among environmental, economic and social goals.

However it should be indicated that EMAS does not include mechanism of selfdisclosure of violations of the environmental legislation, i.e. environmental management and audit system does not cover voluntary notification of competent authorities as regards violations of the environmental law. Environmental auditing could be qualified as a step towards public disclosure of environmental violations.

30 European Commission, Integrating environmental concerns into development and economic cooperation, (Brussels, 1999),

http://glossary.eea.europa.eu/terminology/concept_html?term=environmental\%20audit (accessed June 5, 2008).

${ }^{31}$ Resolution of Ministry of Environment of the Republic of Lithuania, Official Gazette (2002, no. 321220).

${ }^{32} I d$.

${ }^{33} I d$. 
Lithuanian legislation does not provide any penalty mitigation or waiving penalties to companies, which have performed environmental self-auditing, but this fact does not diminish positive importance of the means.

It was provided in the Chapter on Environmental Protection, included in the Lithuanian Common Programming Document of 2004-2006, approved by the Lithuanian Government in 2004, that much attention should be paid to implementation of control, monitoring and management measures in order to control and reduce pollutant emissions into the environment. Implementation of such measures should reduce and limit pollution of the environment. This would create potential for environmental protection, and, in case of emergency, for environmental assessment and the most possible prompt liquidation of the consequences. ${ }^{34}$

The environmental self-auditing, as approved by Lithuanian legislative system, could be expanded by including into this measure the measure of selfdisclosure of violations of the environmental regulations to competent authorities. As a consequence, state competent authorities should be empowered by the right, provided in the law, of mitigation of penalties for infringements of environmental regulations, committed by relevant companies, or of waiving penalties for violations. Legislation should provide clear conditions and criteria, which companies would be obliged to comply with in order to suffer the least possible state enforcement.

In this case it would be possible to make use of the USA experience - for to have the penalties, imposed for violations of environmental regulations, mitigated or waived at all, companies should comply with certain criteria: violations of the environmental law should be disclosed without intervention or instigation of competent authorities, disclosure of violations of environmental regulations must be voluntary, i.e. without any demand, instigation, authorisation or agreement, the violation of the environmental law, which was disclosed after violation of this law, should be disclosed to competent authorities immediately (in the shortest possible period), the violation of the environmental regulations and their consequences must be corrected efficiently, also there must be taken measures for prevention of such violations. ${ }^{35}$

On the other hand, companies in some cases, provided by law, should not be entitled for penalty mitigation or waiver. End again, on the basis of the USA experience, penalties should not be mitigated or there should be no waiving

34 Resolution of the Government of the Republic of Lithuania on approval of Lithuanian Common Programming Document of 2004 - 2006, Official Gazette (2004, no. 123-4486).

35 AQMD Prosecutor's Office, Self-Auditing Policy, (2004), http://www.aqmd.gov/legal/prosecpolicyselfaudit.html (accessed 14 May, 2008). 
penalties for the companies which violate the environmental law by intentional and premeditated actions, or by expressed recklessness, or in case the relevant violation of environmental law caused emission of dangerous substances into the air or caused a public catastrophe, or in case the relevant company has a history of committing the similar violation before. ${ }^{36}$

In conclusion it is possible to claim that state policy in the field of environmental protection must be directed towards introducing and implementation of alternative environmental measures, which encourage compliance with the environmental requirements. One of such measures is a mechanism of environmental self-auditing. The recent analysis demonstrates that environmental audit is an efficient measure for prevention of violations of environmental regulations and for implementation of sustainable development goals. Increasing the notion of environmental self-auditing, embedded in the Lithuanian legislation, by including into it the measure of voluntary disclosure of violations of environmental regulations to competent authorities, would be an important step made towards implementation of sustainable development goals.

\section{CONCLUSSIONS}

Rigidity of command and control regulation mechanism, high costs of implementation of state enforcement, importance of compromise between environmental, economic and social goals determines the need of strengthening and efficient application of the environmental protection measures, encouraging to voluntary compliance of legal entities with the environmental requirements. Voluntary environmental protection programmes, which are based on principle of voluntary bases rather than on mandatory orders, nowadays have become important environmental protection policy measures in industrialised countries. Of them the most efficient measures, ensuring compliance of legal entities with the environmental requirements, are the self-regulatory measure of legal entities, implemented on voluntary bases, known as environmental self-auditing, and voluntary disclosure of violations of environmental regulations mechanism. Legal entities which implement those measures in their company discover compliance of their economic activities with the requirements of the law on environmental protection, collect information about operations they perform, detect deviations from the environmental requirements and this way relieve consequences of violations of environmental regulations, correct those consequences or avoid environmental violations at all. Due to voluntary disclosure of violations of 
environmental regulations mechanism, legal entities disclose their violations of environmental requirements by themselves and remedy the consequences of such violations and, thus, avoid state enforcement or this enforcement is not so strict for the mentioned entities. Environmental self-auditing and voluntary disclosure mechanism has a positive impact both on legal entities and on a state as well: legal entities avoid state enforcement and other negative consequences, and the state saves enforcement implementation costs. Additionally, efficient implementation of the mentioned environmental protection measures is an important means for prevention of environmental violations and also an effective way of achieving sustainable development goals. It should be mentioned that both the European Union and the Lithuanian Republic have acknowledged in their legal regulations and rules the importance of environmental audit, and also have provided implementing measures for this type of audit. If the notion of environmental audit, as it is seen in the European Union and Lithuania, was extended by making use of the USA experience, namely by adopting voluntary disclosure of violations of environmental regulations mechanism, thus would be possible to expect even more efficient impact of environmental audit in the context of implementation of sustainable development goals.

\section{BIBLIOGRAPHY}

1. AQMD Prosecutor's Office. Self-Auditing Policy (2004) // http://www.aqmd.gov/legal/prosecpolicy-selfaudit.html (accessed 14 May, 2008).

2. Blackman A., Lyon T. P., Sisto N. "Voluntary Environmental Agreements When Regulatory Capacity Is Weak." (2006) // http://www.rff.org/Documents/RFFDP-06-30.pdf (accessed January 14, 2008).

3. Business and Industry Advisory Committee to the OECD. BIAC Statement "Voluntary Approaches in Environmental Policy." (October 1998) // http://www.biac.org/statements/env/clim/VApositionpaperFINAL.pdf (accessed February 15, 2008).

4. Environmental Commissioner of Ontario. Discussion Paper For Round Table On Self Regulation, Voluntary Compliance And Environmental Protection. (October 1996) // http://www.eco.on.ca/english/publicat/rndtbl1.pdf (accessed February 18, 2008).

5. Environmental Protection Agency. Incentives for Self-Policing: Discovery, Disclosure, Correction and Prevention of Violations. (May 11, 2000) // 
http://www.epa.gov/compliance/resources/policies/incentives/auditing/auditp olicy.pdf (accessed February 23, 2008).

6. European Commission. Integrating environmental concerns into development and economic cooperation. (Brussels, 1999) // http://glossary.eea.europa.eu/terminology/concept_html?term=environmenta 1\%20audit (accessed June 5, 2008).

7. Kesan J. P. "Encouraging Firms to Police Themselves: Strategic Presentations to Promote Corporate Self-Auditing." University of Illinois Law Review 155 (2000) // http://ssrn.com/abstract=263835 (accessed May 25, 2007).

DOI: $10.2139 /$ ssrn.10.2139/ssrn.263835.

8. Lyon T. P., Maxwell J. W. "Self-regulation, taxation and public voluntary environmental agreements." Journal of Public Economics 87 (2003) // http://webuser.bus.umich.edu/tplyon/LyonMaxwellJPubE.pdf (accessed May 3, 2008).

DOI: $10.1016 / S 0047-2727(01) 00221-3$.

9. Lyon T. P., Maxwell J. W. '"Voluntary' Approaches to Environmental Regulation: A Survey." (January 1999) // http://ssrn.com/abstract=147888 (accessed January 14, 2008).

DOI: $10.2139 /$ ssrn.10.2139/ssrn.147888.

10. Paquin M., Sbert C. "Towards Effective Environmental Compliance and Enforcement in Latin America and the Caribbean." (2004) // http://www.unisfera.org/IMG/pdf/New_approaches_to_environmental_protect ion_vfinale3_ajout_.pdf (accessed January 14, 2008).

11. Pfaff A. S., Chris W., Lee J., Prager D. "Big Field, Small Potatoes: An Empirical Assessment of EPA's Self-Audit Policy." UVA Law and Economics Research Paper No. 02-02 (2004) // http://ssrn.com/abstract=307241 (accessed 23 February, 2008).

DOI: $10.2139 /$ ssrn.10.2139/ssrn.307241.

12. Productivity Commission. "Implementation of Ecologically Sustainable Development by Commonwealth Departments and Agencies." Report No. 5 (Canberra, AusInfo, 1999) // available through www.pc.gov.au (accessed February 18, 2006).

13. Ray H. M. "Promoting Corporate Self-Compliance: An Examination of the Debate Over Legal Protection for Environmental Audits." 23 ECOLOGY L.Q. 663 (1996).

14. Regulation (EC) No 761/2001 of the European Parliament and of the Council of 19 March 2001. Official Journal L: 200104 24, no.114-1. 
15. Resolution of Ministry of Environment of the Republic of Lithuania. Official Gazette, 2002, no. 32-1220.

16. Resolution of the Government of the Republic of Lithuania on approval of Lithuanian Common Programming Document of 2004 - 2006. Official Gazette, 2004, no. $123-4486$.

17. Rubel F. N. "The Basics of EH\&S Self-Auditing." EM, A\&WMA's Magazine for Environmental Managers (2006) // http://www.environmentalexpert.com/resulteacharticle4. asp?cid $=6477 \&$ codi $=5984$ (accessed November 28, 2006).

18. Sanchirico C. W., Pfaff A. "Environmental Self-Auditing: setting the proper incentives for discovery and correction of environmental harm." Journal of Law, Economics, and Organization Vol. 16, No. 1 (April 2000): 189-208(20) // http://jleo.oxfordjournals.org/cgi/content/abstract/16/1/189 (accessed 23 February, 2008).

19. Short J. L., Toffel M. W. "Turning Themselves In: Why Companies Disclose Regulatory Violations." Working Paper Series Paper 17 (2005) // http://repositories.cdlib.org/crb/wps/17 (accessed 23 February, 2008).

20. Stafford S. "Does Self-Policing Help the Environment? EPA's Audit Policy and Hazardous Waste Compliance." Vermont Journal of Environmental Law 6 (2004-2005) // http://www.vjel.org/journal/VJEL10022.html (accessed May $21,2008)$.

21. Uchida T., Ferraro P. J. "Can Encouraging Voluntary Development of Environmental Management Systems Augment Existing Regulations?" Water Policy Working Paper \#2005-015 (2005) // http://www.h2opolicycenter.org/pdf_documents/water_workingpapers/2005015.pdf (accessed March 4, 2008).

22. UNEP Multi-Stakeholder Workshop on Voluntary Initiatives. "Voluntary Initiatives: current status, lessons learned and next steps." UNEP discussion paper (September 20, 2000) // http://www.uneptie.org/outreach/vi/reports/voluntary_initiatives.pdf (accessed August 8, 2006). 